
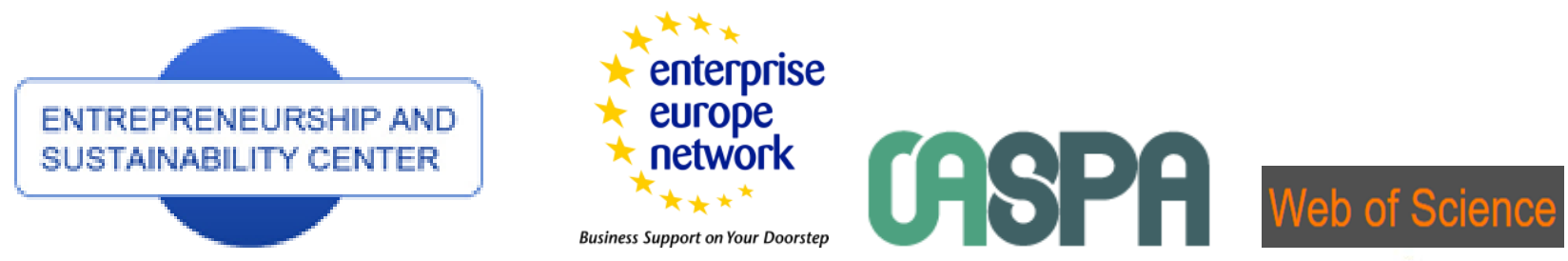

Clarivate
Analytics

Publisher

\title{
THE ABILITY OF LISTED COMPANIES TO OPTIMIZE THEIR CAPITAL STRUCTURE, SHAPE THEIR DISTRIBUTION POLICY AND FIGHT HOSTILE TAKEOVERS BY REPURCHASING THEIR OWN SHARES
}

\author{
Daniel Schwarz \\ Pan-European University, Faculty of Economics and Business, Tematínska 10, 851 05, Bratislava; Slovakia \\ E-mail: $\underline{\text { SchwarzDaniel@gmx.at }}$
}

Received 15 May 2018; accepted 22 October 2018; published 30 December 2018

\begin{abstract}
The management of listed companies is faced with the decision to distribute the annual surplus to the shareholders in total or to reinvest it in order to achieve the company's goals in order to sustain the continued existence and growth of the company. In order to avoid a conflict of interest between the various parties of a stock corporation, compensation must be found so as not to jeopardize the company's goals and priorities. An optimization of the capital structure and a balanced dividend policy should contribute to the satisfaction of all stakeholders of a company. This article investigates the possiblity by using a share buy-back programm, a kind of capital reduction, as a strategic measures to reach both oft he goals. Sustainability in terms of financial stability should be at the forefront of management and ownership.
\end{abstract}

Keywords: Buy-back programm (BBP); reconciliation of interests; capital reduction; optimal capital structur; distribution policy; hostile takeover

Reference to this paper should be made as follows: Medaiskis, T.; Gudaitis, T.; Mečkovski, J. 2018. Second pension pillar participants' behaviour: the Lithuanian case, Entrepreneurship and Sustainability Issues 6(2): 636-648. http://doi.org/10.9770/jesi.2018.6.2(12)

JEL classification: G32, G34, G35, G38

\section{Introduction}

One of the current and most important economic issues of our day is the share buybacks of listed companies. This is reflected in the total repurchase activity of the largest US listed companies between 2013 and 2016, with more than $60 \%$ of their constant free cash flow with a huge index total of more than $\$ 900$ billion (see Figure 1). It reached the same volume as immediately before the financial and economic crisis. Apple alone, IBM, Exxon Mobile, Pfizer and Oracle invested more than \$ 90 billion in 2014 (compared to 25 billion in the EU) in share buybacks. It is not a phenomenon limited to the United States, but an international trend. 
Due to the uncertain economic development of recent years, the number of share buyback programs in Europe has been lower than in the the United States, although international European companies (eg BP, Royal Dutch, Novartis and British American Tobacco) have made similarly high profits as US companies. Another reason for the diverging trends was the lack of past experience with buybacks, unclear tax regulations and the upcoming financial liberalization in Europe. In addition to dividend payments, US companies were able to reduce their debt by $40 \%$ through share buybacks. The listed companies of the Stanley \& Poor's 500 Index hold $\$ 4.2$ trillion in cash.

In Austria, share repurchase programs (BBP) amounting to between 5 and $10 \%$ of the share capital of resident companies have been decided and started in the last 5 years. The main companies were companies in the fields of technology, real estate and energy (eg Apple Austria, Telecom AG, CA Real Estate, Andritz AG, Maschinenfabrik Heid AG, Mayr Melnhof Karton AG, Austrian Post AG, EVN, Frauenschuh, 2014).

At first glance, one could attribute earning capacity to those companies that have invested their earned free cash flow in repurchasing their own shares than in the company's growth. But does not this just prove lack of ideas and investment opportunities in your own core business? In addition, this development benefited from weak economic growth as well as low interest rates, which made it possible to obtain favorable borrowing (Frauenschuh, 2014).

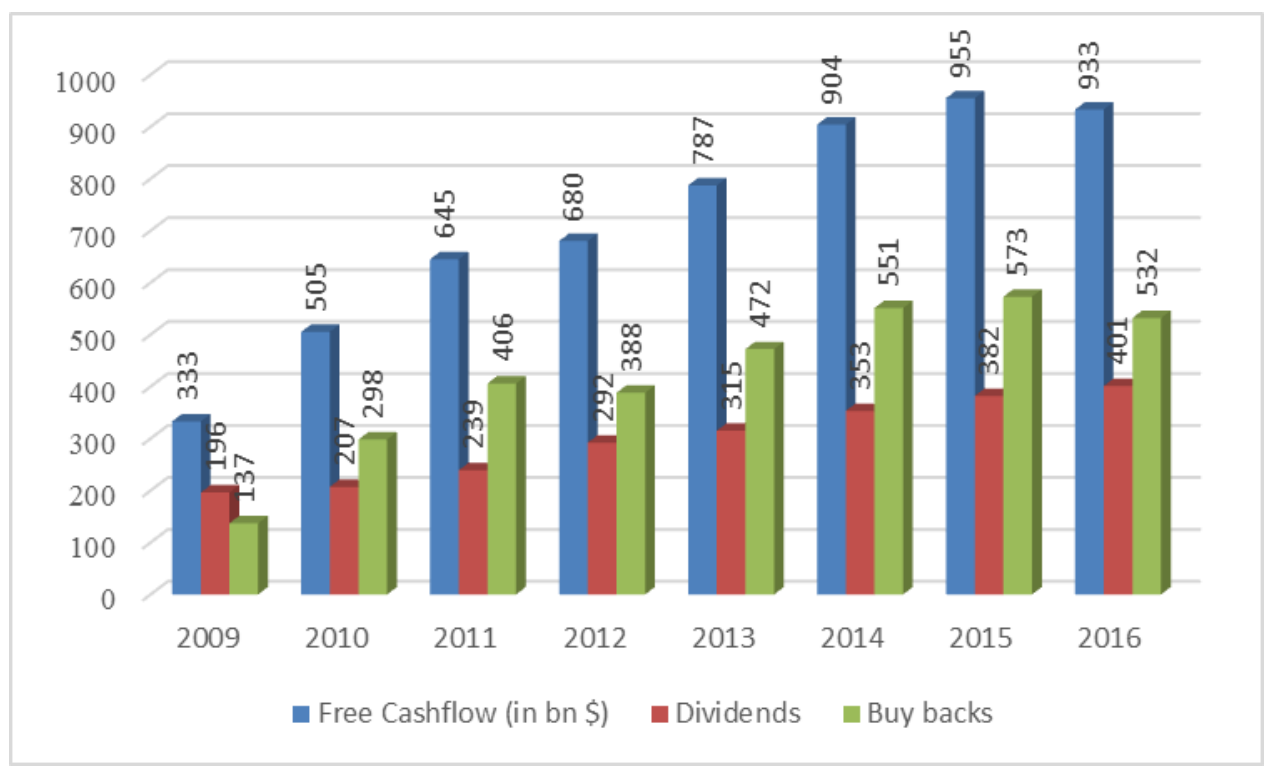

Figure 1. Development of share buybacks according to S \& P 500 Source: $\underline{\text { http://spindices.com }}$

In view of this explosive development, investors are questioning the dividend policy (Walchshofer, 2013), the analysts the motives of the management (Schmal, 2016) and the stakeholders questioning the company as a social value-adding institution (Freeman, 2010). In this field of tension, the trust of the owners in the company decisions is of great importance. The corporate constitution can provide security between management and owner (Schewe, 2005). In turn, corporate governance obliges corporate management to correct decisions in the target achievement processs (Wentges, 2013). In practice, the share repurchase can be used as an instrument to control the capital structure and dividend policy, as well as aspects of credit quality, operational lifecycle phases and defense against takeovers (Staroßom, 2012). 
The International Journal
ENTREPRENEURSHIP AND SUSTAINABILITY ISSUES

ISSN 2345-0282 (online) http://jssidoi.org/jesi/

2018 Volume 6 Number 2 (December)

http://doi.org/10.9770/jesi.2018.6.2(12)

\section{Material and Methodology}

The motives of starting buy back programs are very different and are shaped according to the ideas of two interest groups, the management and the shareholders (see Tab. 1), within the framework of the legal rules. It is therefore of great importance for the management, in order not to jeopardize the stability of the company and to create a balance of interests between share- and stakeholders. While the management aims for the positive development of the company, the shareholders, ideally, want a successful, long-term increase of their investment. You can distinguish the motives of both groups based on their corporate strategy and security pretense. A shareholder is not only interested in a payout, but also in the security of getting it in the future, otherwise he could invest his money in another company. Table 1 also identifies the strategic interests of management based on enumerated motives that serve to bring the company under even greater control. A buyback program can also convey the impression of lack of decision-making authority, unsuccessful market strategies and the lack of market-related growth prospects (Bösch / Ude, 2014).

The motives for profit distribution and reserve policy are based on target achievement strategies and the current possible success situation (Prätsch et al., 2012). The continued existence of the company will be ensured in the long term by planned debt repayments and investments, with the effects of modernization, development of new product, further expansion and stronger establishment in markets and business areas (Eilenberger et al., 2013). In particular, mature, high-profit products require long-term innovation and technical adjustments to avoid sales slumps (Portisch, 2008 \& Porter, 2013).

In order to provide sufficient funds for investments, repayments and reserves, management makes decisions regarding income taxes and dividend payments. While taxes are defined under tax law, dividend policy must take into account the interests of all parties involved. Basically, decisions are made in the sense of improving the company situation. Thus, the profit distribution including the accumulation by owner interests, corporate strategies or signaling, the public advance notice of a possible BBP, may be affected (Guserl \& Pernteiner, 2015).

Table 1. Motives for the share buyback

\begin{tabular}{|l|l|}
\hline \multicolumn{1}{|c|}{ Financial policy motives } & \multicolumn{1}{|c|}{ Shareholder political motives } \\
\hline $\begin{array}{l}\text { Distribution of excess liquidity } \\
\text { Optimization of the capital structure and capital cost reduction by using } \\
\text { the leverage effect }\end{array}$ & $\begin{array}{l}\text { Defense of unfriendly takeover attempts } \\
\text { Use of own shares as transaction currency for } \\
\text { company takeovers } \\
\text { Improvement of the company key figures }\end{array}$ \\
$\begin{array}{l}\text { Signaling at undervaluation } \\
\text { Influence on the shareholder structure } \\
\text { Reduction of agency costs }\end{array}$ & $\begin{array}{l}\text { Serving stock option programs for employees } \\
\text { Distribution via share buyback due to tax benefits }\end{array}$ \\
Listing on a foreign stock exchange & \\
\hline
\end{tabular}

Source: Bösch M./Ude E. (2014)

Due to the accounting policy, the company management sets, within the applicable law, accents to satisfy the satisfaction of the company's close groups. Measures taken, e.g. Recognition and valuation options can influence the current and future taxable profits (Lembke, 2009). Critical are too high valuations of future manufacturing and research \& development and marketing expenses (Schierenbeck, 2003).

International companies also use different taxrates in the countries of their subsidiaries. The retroactive taxation of profits in the country of the parent company takes place i.a. based on a dividend distribution less deductions from international income tax regulations. The corporate governance strategy is eager to meet owners' demands for 


\section{The International Journal}

ENTREPRENEURSHIP AND SUSTAINABILITY ISSUES

ISSN 2345-0282 (online) http://jssidoi.org/jesi/

2018 Volume 6 Number 2 (December)

http://doi.org/10.9770/jesi.2018.6.2(12)

maximizing assets through tax breaks by adjusting period results, as high profits generate high taxes and reduce the proportion of investors in the company (Staroßom, 2012).

Optimizing the capital structure is important for companies to achieve lower capital costs, strengthen financial stability and improve credit-worthiness. There is no ideal theory (Guserl \& Pernsteiner, 2015). The goal of the traditional approach (leverage) e.g. is the increase in equity. Borrowed capital should only be raised if it is cheap and its costs are not higher than the total profitability (Schmidlin, 2013). The agency approach, which incorporates the information advantage of management vis-à-vis lenders, in turn aims to provide a high level of equity. However, the freedom of design of management can lead to increasing indebtedness, risky investments and an imbalance in the capital structure. The entrepreneurial capital structure is determined not only by the different aspects and ways of thinking, but also by factual and event-related influencing factors such as capital increases, reductions, borrowings and above all through the distribution or dividend policy (Guserl \& Pernsteiner, 2015).

The dividend policy serves to balance the interests of the company and the shareholders. The important points are the time and the amount of the distribution. The management and the supervisory board decide to use the surpluses of the financial year in compliance with the rules of the tax law, the bookkeeping and reserve policy (Perridon, Steiner \& Rathgeber, 2014). The starting point is the generated free cash flow, the excess amount from the capital employed and the reinvestment. It serves in addition to the debt repayment of the dividend payment (Schmidlin, 2013).

Management uses the buy-backs as signal function in times of excellent corporate development by announcing dividend increases. This also suggests product improvments and a mature and saturated market and financial slumps. Accumulated surpluses increases the risk of hostile takeovers. In this case, the terms and conditions of acquisition will be improved until they are finally accepted by the corporate officers. High corporate liquidity surplus results in so-called bootstrap acquisitions. In the process, the takeover company finances the property with liquidity surpluses of the object of purchase (Guserl \& Pernsteiner, 2015 \& Staroßom, 2012).

Sustainable, successful and secure business policy is fundamentally based on a solid equity base. This is necessary to ensure ongoing product innovation, process improvements, international expansion and financial stability. Company helps a strong innovation orientation towards crisis susceptibility and coping. Further aspect in this regard enterprise size and environmental dynamics (Rößl et al., 2013). Companies with mature products in saturated markets are reacting with further developments or replacement products even before the sales slump. If the owners demand a profit distribution and the reserve volume is insufficient, the management should consider a capital reduction and inform the supervisory board about the situation (Prätsch et al., 2012 \& Staroßom, 2012).

In the case of capital reduction, the literature distinguishes between ordinary, simplified or with the collection of own shares. The instrument serves to avoid losses or in case of reorganization. For the ordinary capital reduction, a majority resolution of the general meeting is required (creditor protection). It is made by reducing the nominal amount of the share, repaying it to shareholders or reducing its deposit obligations. It serves the repayment of capital to the shareholders. The decision must be entered in the commercial register. There is a lock-up period in which all creditors are satisfied before the payment to the shareholders.

The simplified capital reduction provides for an alignment of the share capital with the actual company assets. There is no payout, nor to release the deposit obligations. The capital reduction serves to cover losses as well as the cessation of tied reserves (max. 10\% of the adjusted share capital). A profit distribution is only possible after 5 years, following a resolution by the Annual General Meeting. The simplified capital reduction is used in 
restructuring cases and is combined with a capital increase to attract funds and investors (Crone, 2014 \& Aigner et al., 2009).

The third form of capital reduction is the retirement of shares. This can be done by repurchasing $10 \%$ of own shares or by compulsory redemption of shares. Genearlly the sale of own shares is in the Stock Corporation act of different European countries prohibited, as it leads to a reduction of the nominal capital or the liable capital (protection of creditors). However, sales authorizations may be granted, in the event of imminent serious damage, or in the case of offers to employees, members of the Supervisory Board, the Management Board and the remuneration of minority shareholders.

The buyback of own shares reduces equity. Remaining surpluses, without investment use, are distributed to the owners. The stock price itself remains the same, while the price is reduced by the dividend payment. When acquiring own shares, the nominal value is shown as a negative position against the share capital. The difference is allocated to retained earnings so that they are not used for distribution and payment to the owners.

One of the main motives for the share buyback is that one expects rising prices due to the positive business development and an announcement of dividend distribution and thus a price adjustment, the so far undervalued shares is brought about. Further motives may be based on employee participation, issue on foreign stock exchanges, adjustment of the investment structure or future stock market retreat (Aigner et al., 2009).

The BBP is proposed by the Executive Board and the Supervisory Board and initiated by the Annual General Meeting by means of a five-year limited authorization. Information obligations exist to the financial market supervisory authority, the stock exchange, as well as to owners and interest groups.

The executive committee publishes a prospectus, which announces the beginning, the term and the total volume. In the financial statements, the shares sold are presented in the balance sheet and explained in the notes to the annual report. The authorization ends with the end of the BBP (Sendel-Müller, 2009). In the EU (European Union), share buybacks were made possible by the capital guidelines. In Germany and other countries, the capital reduction was legitimized with the obligation to control and transparency of the companies (Frei \& Schlienkamp, 1999).

The requirement for the topic is, in addition to a holistic view, to examine the BBP as a financial-strategic instrument. Based on the described motives, the design of the optimal capital structure and dividend policy shall be examined. In order to give the topic the necessary relevance, a practical calculation example will provide information in addition to the literature.

As stated in the introduction, executives of corporations use BBP to reduce annual surpluses and thus curtail different interests. In order to carry out this program, the corporate leadership needs persuasiveness to enforce its motives. If the balance of interests with the shareholders and stakeholders succeeds, the program can be started with the goal of optimizing the capital structure and the adopted dividend policy. Managers are expected to create the best possible conditions for achieving their business goals, based on their knowledge advantage (Guserl \& Persteiner, 2015).

The paper tries to prove the effects of a BBP regarding the optimization of the capital structure and the dividend policy with the following theses:

- Hypothesis 1: The BBP improves the capital structure. This leads to an improvement in the credit rating of the company. 
- Hypothesis 2: The BBP aims to avoid high dividends in order to prevent hostile takeovers.

This investigation has a strong emphasis on the stability of the company through share buyback programs. In addition to the fiscal goals, the further development of the products and the concentration on the core business should not be forgotten.

\section{Results}

In the following, the optimization of the capital structure and dividend policy and the underlying motives, in a capital reduction of listed companies by the collection of shares are presented. In addition to the explanations on the theoretical approaches, key figures and analyzes should provide clarity on the established hypotheses.

The search for the optimal capital structure primarily serves to maximize total profitability and thus goodwill (Ehringer et al., 2013). Current literature relies on theories of leverage and the traditional approach in their studies of optimal capital structure (Guserl \& Pernteiner, 2015). With the result that no optimal capital structure can be determined, since both theories include different starting points and influencing factors. The Irrelevance thesis of Modigliani and Miller $(1958,1961)$ starts from the perfect market, which neglects taxes, illiquidity and considers capital structure changes as irrelevant for shareholders. These assumptions led to discussions regarding the inclusion of individual decisions and operational structural characteristics (Guserl \& Pernsteiner, 2015 \& Staroßom, 2012). In the following, it is attempted, irrespective of these theories, to approximate an optimal capital structure.

According to international accounting standards (IAS), share buybacks reduce equity by selling costs. The consequences are the increase in the debt-equity ratio of the company as well as the threat to the protection of creditors (Bösch / Ude, 2014). Basically, the more equity, the higher the creditworthiness. Due to its interest rate and risk, equity is more expensive than borrowed capital, which can be obtained more easily by good creditworthiness and the costs can be deducted for tax purposes (Wagenhofer, 2008).

The optimal ratio between equity and debt capital can be calculated using the capital structure key figures as follows (Schmidlin, 2013 \& Becker, 2009):

- The return on equity (1) is the interest on the shares held by the owners. The higher the debt ratio, the higher this ratio.

- This assumption applies as long as the return on capital (2) is higher than the cost of borrowing costs.

- Another measure of financial stability is the so-called gearing (3), the net debt to equity.

In the following simplified example, four assumptions have been made and are shown in the connected table and figure (taxes are not included):

a) Y-1: opening balance, borrowing interest rate $5 \%$,

b) Y without loan: the previous year's funds were not distributed but used for the repayment of debts, the better credit rating was agreed to a new interest rate of $4 \%$,

c) Y loan: the profit was distributed, a new loan has been taken ( $6 \%$ interest),

d) Y mix: The profit was completly used for dividend distribution (50\%) and debt repayment (50\%).

e) Y BBP: The profit was used for the repurchase of shares (50\%), for the dividend distribution and debt repayment, therefore a new borrowing interest rate of $4 \%$ was agreed. 
Table 2. Development of the balance sheet structure

\begin{tabular}{|l|r|r|r|r|r|}
\hline \multirow{2}{*}{$\begin{array}{c}\text { Ratios/Positions } \\
\text { in EURO) }\end{array}$} & \multicolumn{1}{|c|}{ Y-1 } & \multicolumn{4}{c|}{ Y } \\
\cline { 2 - 6 } balance & $\begin{array}{c}\text { Opening } \\
\text { loan }\end{array}$ & \multicolumn{1}{c|}{ loan } & \multicolumn{1}{c|}{ mix } & \multicolumn{1}{c|}{ BBP } \\
\hline ROE & $20 \%$ & $19 \%$ & $16 \%$ & $19 \%$ & $20 \%$ \\
ROI & $11 \%$ & $11 \%$ & $10 \%$ & $11 \%$ & $10 \%$ \\
Gearing & $30 \%$ & $10 \%$ & $50 \%$ & $20 \%$ & $25 \%$ \\
\hline Proportion per share & $10 \%$ & $10 \%$ & $10 \%$ & $10 \%$ & $11 \%$ \\
\hline Liquide Funds & 500 & 500 & 500 & 500 & 500 \\
\hline Sharehoder's Equity & 5.000 & 5.000 & 5.000 & 5.000 & 5.000 \\
\hline Retained earnings & & & & & -500 \\
\hline Liablities & 2.000 & 1.000 & 3.000 & 1.500 & 1.750 \\
\hline Debt Capital & 5.000 & 4.000 & 6.000 & 4.500 & 5.000 \\
\hline Total Capital & 10.000 & 9.000 & 11.000 & 9.500 & 9.500 \\
\hline EBIT & 1.100 & 1.000 & 1.000 & 1.000 & 1.000 \\
\hline Interest on outside Capital & -100 & -40 & -180 & -75 & -70 \\
\hline Net Income & 1.000 & 960 & 820 & 925 & 930 \\
\hline
\end{tabular}

$R O E=\frac{\text { Net Income }}{\text { Dhaneholder'sequity }}$

$R O I=\frac{(\text { Net Income }+ \text { interest on outside capital) }}{0 \text { Total Capital }} \times 100$

Gearing $=\frac{\text { Interest bearing net-liquid funds }}{\text { Shareholder'sequity }}$
(1)

(3)

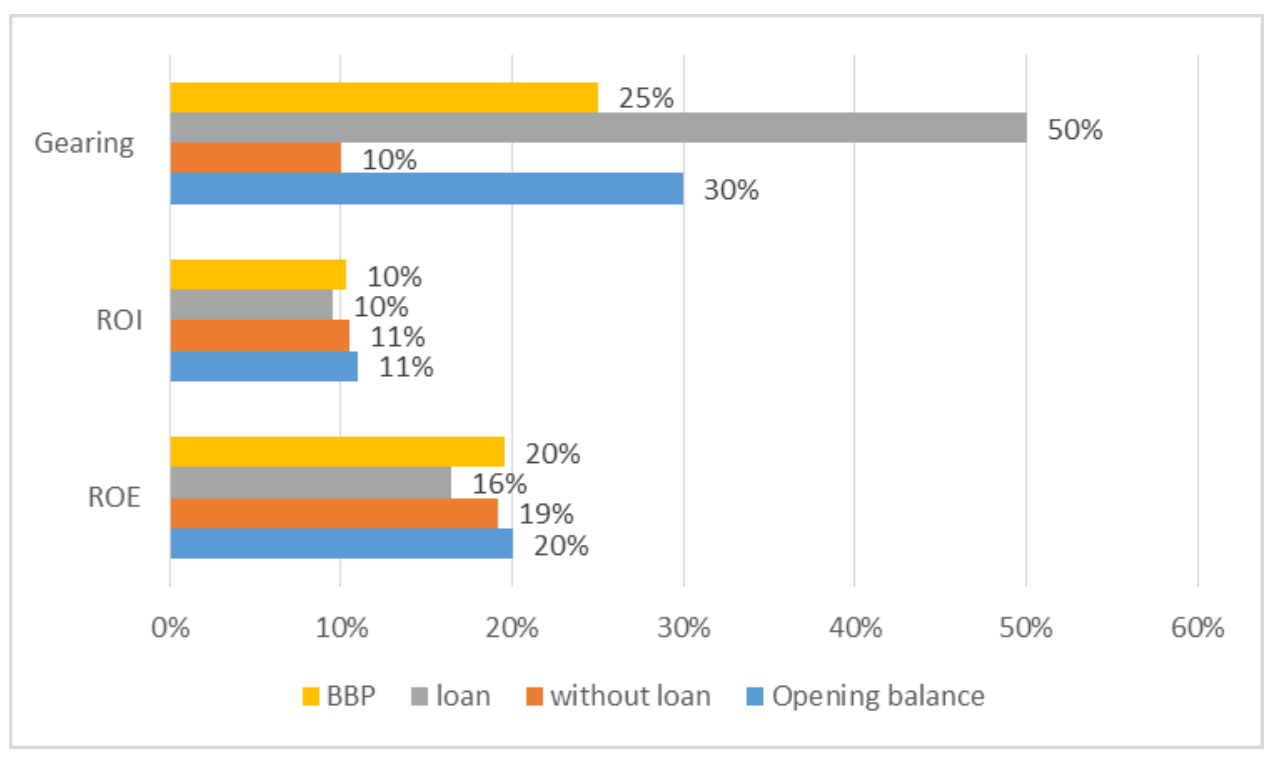




\section{The International Journal}

ENTREPRENEURSHIP AND SUSTAINABILITY ISSUES

ISSN 2345-0282 (online) http://jssidoi.org/jesi/

2018 Volume 6 Number 2 (December)

http://doi.org/10.9770/jesi.2018.6.2(12)

Figure 3. Capital structure ratios; Source: own research

As shown in Tab. 2 and Fig. 3, the total distribution with simultaneous borrowing (assumption c) has a negative effect on the return on equity and a significant negative development of the debt ratio, because auf the new loan. While b) due to the improved creditworthiness could be arranged with the bank more favorable rates these remained the same for c) + e). Assumption b) focused on the repayment of debts in the amount of the annual surplus but to the burden of a missing dividend distribution.

The BBP used the proceeds for the share repurchase, the partial distribution $(25 \%)$ and the loan repayments (25\%). The result was an decrease of the debt ratio compared to the previous year, which helped shows an optimization of the capital structure (Pernsteiner \& Andressner, 2014). Despite BBP's 50\% use of the surplus, the BBP improved its financial structure and its share quota of share capital increased by one percentage point. In this case, despite a reduction in equity, there was an interest compensation with creditors and shareholders.

The examples are very different. Thus, in one case, a distribution defying high profits was waived to repay debt. The other variant, was a uniform distribution of dividend payment and debt repayment. The BBP achieved the same effects of the two approaches presented. However, in addition to the performance improvement, a rectification of the shareholder structur was effected. The strengthening of the creditworthness helps the company to borrow cheap money. However, these excellent figures can change significantly due to poor operating results.

High profits are necessary because of the interest on borrowed capital, the protection of creditors and a dividend policy designed in the interests of reconciliation of interests and shape the composition of the capital structure. For companies in the maturity phase, market saturation leads to sales and profit losses. Thus, it can be stated that there is no operational increase in profitability, because in addition to the profit potential loss potentials are also increased, so the structural policy, as the example shows, is suitable for lower interest rates (Bösch / Ude, 2014).

Companies with high surpluses, combined with low reinvestment requirements and a high potential for distribution, attract willing-to-take competitors or investment companies. By contrast, companies with high product maturity need to achieve innovation or new combinations of goods by investing in research and development quickly and extensively. With the distribution policy, corporate executives control the surpluses. The defensive strategy of threatened companies can be achieved by reducing the company's economic incentives through share buybacks, resulting in increased equity value, reducing the total number of shares, and initiating stock option programs for employees from whom companies can expect loyalty. (Bösch / Ude, 2014 \& Johannsen-Roth (2001)).

The Stock Corporation Act regulates the general conditions for the appropriation of profits and thus sets the legal framework for the dividend policy. The owner shareholder is entitled to a profit, unless there are restrictions by law or statutes. Up to max. $50 \%$ of the surpluses can be retained by the Management Board and the Supervisory Board as retained earnings. In the case of a capital reduction, however, a profit distribution of more than $4 \%$ is only possible after two years from the date of liquidation. Creditors are not affected due to creditor protection. Reserves that are dissolved by the capital reduction must not be distributed as profit. As can be seen from the statutory provisions of the Stock Corporation Act, there are a number of possibilities to develop a dividend policy within the framework of the law and in the interests of all parties (Austrian Stock Corporation Act).

If a listed company is the target of a hostile takeover, the corporate executives, if it is against their will and to the detriment of taking over, will vigorously try to prevent this. The "receiving party" offers owners an offer to take over their shares. Most of the payments are financed through leverage buyouts in order to hide the intention to buy, or to undermine the long-winded acquisition via equity issues (Macharzina \& Wolf, 2014). The repurchase 
of own shares can be used as a tool against hostile take-overs. However, the scope is limited to $10 \%$ of the nominal capital. Therefore, the solution can be found in the procedure and use of the interactions.

The realization of the BBP leads to a reduction in equity. If borrowing is financed, this increases the debt-equity ratio and thus the reduction of the company's liquidity, which is reflected in the purchase price/risk of the company shares (Johannsen-Roth, 2001). Another approach is to submit offers to sell-willing shareholders so that the shares remain in the company. Thus, an adjustment of the shareholder structure, a so-called squeeze-out, is achieved in the case of heterogeneous groups (Schremper, 2002). Another, but rather expensive, option is to buy back the shares directly from the "transferee" with an additional standstill agreement (Johannsen-Roth, 2001).

The results presented here showed the possibilities of share buyback programs for the executives of listed companies. Thus, by reducing excess liquidity through share repurchases, the capital structure and creditworthiness can be improved, shareholders and creditors can be equally satisfied. It can thus be tempted to strike a balance of interests between the goals of the company and the shareholders, by downsizing and improving the shareholder structure. Using several scenarios and relevant key figures, the author has tried to clearly illustrate the answers to both hypotheses. Recently, the design of working strategies, restricted by legal regulations, was explained to combat hostile takeovers.

\section{Discussion}

In the previous chapters, the motifs of a share buyback program known in the current literature were generalized and two motifs of them were hypothesized in particular. In principle, the repurchase of own shares is generally viewed critically. Arguments that reinforce these doubts:

- Financial resources that are used through disorderly repurchases without fsical effects,

- surpluses that are not invested in innovation and new product development as a result of the share repurchase are particularly important for mature products and mature markets,

- major shareholders, who only have the profitability of their deposits in mind and

- managers who abuse the share buyback to gain more personal goals, influence and power

According to hypothesis 1, the BBP was presented in this paper as an instrument for optimizing the capital structure using a practical calculation model with key figures. The result of the assumptions underlying the model showed an improvement in creditworthiness, which in turn leads to borrowing. Balanced capital resources/components are needed to achieve corporate goals more flexibly and better. However, companies prefer a weaker return on equity, as fresh loans are cheaper than equity, because of expected returns, and are tax deductible.

With regard to the dividend policy within the framework of the BBP, according to hypothesis 2, it can be stated that the legal provisions limit the possibilities. An applied strategic approach in the legal framework and a resultsbased approach can prevent impending hostile takeovers.

With these two design possibilities, the influence and scope for action of the company management can be strengthened. This creates the opportunity to drive product development in the long term, to focus even more on the markets, to improve the shareholder structure and to sustainably strengthen the autonomy of the company..

Whether these two measures belong to the most pressing priorities of listed companies was not answered in this paper. For reasons of simplification, two design measures have been taken which are practical and not abstract. 
In the literature, in connection with BBP, critical motives such as signaling or subsequent taxation of foreign profits are discussed. As one can see from these issues, the implementation of the BBP offers a multitude of further depths that can be used to question the motives of the corporate officers.

\section{Conclusion}

This paper describes two motives of a worldwide fiscal phenomenon of our time - the instrument of the share repurchase of listed companies. In the United States, the so-called BBP is one of the corporate finance strategies. In Europe, so far, legal regulations have limited these programs. Another reason was the critical attitude of investors and stakeholders towards non-transparent fiscal decisions. However, this tool, when properly implemented, has the potential to make distributions efficient and can balance the operational needs and interests of shareholders.

The motives for launching a BBP are very different but of great scope and can be differentiated according to fiscal and investor-oriented corporate decisions. While the shareholder expects higher returns on his invested capital, the managers of the companies set themselves the goal of successfully developing the company

Corporate executives of listed companies have the option of paying out surpluses to owners, taking account of the accumulation of reserves and accumulating them, or using them to finance capital reductions in the form of share repurchases. At the forefront of these decisions are the balancing of the different interest groups and the balance between the financing consideration and the distribution policy. A tension that is characterized by the knowledge advantage of the management, the desire for control by the owners (corporate governance) and the hope of the stakeholders for the survival of the company.

The result of the study shows in the first step the elaboration of the proposed hypothesis of the optimization of the capital structure. Responses were made by using current literature and an annotated analysis with four developed scenarios. Specific key figures underline the vigor of the given examples. The result of the BBP example shows an improvement of the total return on equity, the debt ratio and thus a higher return on capital employed. These are reasons that increase creditworthiness and confidence in the actions of the manager.

The danger of hostile takeovers, but also market-related inflexibility can be dispelled by leveraged, strategic BBP. The target takeover-willing company is aimed, as already mentioned, at businesses with high surpluses, combined with low reinvestment requirements and a high potential for distribution. In case of a specific and real threat, the company can react with a BBP. As the ability to repurchase shares is limited by law, the effectiveness of the program, combined with a number of monetary and structural measures, can effectively combat a potential takeover. Thus, the risk of hostile takeovers, in case of market inflexibility deployed by strategic deployed BBP.

The impact of both measures described and objectives examined confirms successful credit quality improvement and the prevention of hostile takeovers.

The subject of share repurchase includes, in addition to the different interests and motives possibilities for further studies. The dynamics of globalization require answers, new ways and more flexible thinking and action from the leaders of listed international companies. A BBP is one of the tools that, if applied correctly, can provide solutions based on its motives.

Finally, it must be noted that lengthy and complicated BBP can be dispensed with by weighing the interests of the parties concerned. High and regular surpluses can be shared through a balanced distribution policy with stable 


\section{ENTREPRENEURSHIP AND SUSTAIN \\ The International Journal}

ISSN 2345-0282 (online) http://jssidoi.org/jesi/

2018 Volume 6 Number 2 (December)

http://doi.org/10.9770/jesi.2018.6.2(12)

dividends (in the interest of shareholders), adequate provision and a reduction in the risk of takeover-willing companies (in the interest of stakeholders).

\section{References}

Aigner, D. J., Aigner, H. J., \& Aigner, J. (2009). Krisen-und Sanierungsmanagement [Crisis and restructuring management].

Becker, H. P. (2009). Finanzwirtschaftliche Ziele [Financial goals]. In Investition und Finanzierung, engl. Financial targets. In investment and financing (pp. 9-27). Gabler Fachbereich Betriebswirtschaft. https://doi.org/10.1007/978-3-8349-9534-6_2

Bösch, M., \& Ude, E. (2014). Share repurchase program in Germany (No. 01/2014). Economical writings, series: Finance and capital markets, University of Applied Sciences Jena, Department of Business Administration.

Crone, A., Werner, H., Abel, P., Allert, A., Bisson, F., Vorholt, A. G. \& Pleßke, C. (Eds.). (2010). Modernes Sanierungsmanagement [Modern reorganisation management] Vahlen.

Ehringer, G., Ehrenhöfer, R., \& Zschockelt, I. (2013). Kapitalstruktur-Management und Finanzierungsregeln. Die neue Unternehmensfinanzierung: Strategisch finanzieren mit Bank-und Kapitalmarktorientierten Instrumenten [Capital structure management and financing regulations. N New Corporate Finance: Strategic Finance with Bank and Capital Markets Instruments], 58.

Eilenberger, G., Ernst, D., \& Toebe, M. (2013). Betriebliche Finanzwirtschaft: Einführung in Investition und Finanzierung, Finanzpolitik und Finanzmanagement von Unternehmungen [Corporate Finance: Introduction to in nvestment and financing, fiscal policy and financialmanagement of companies]. Walter de Gruyter.

Frauenschuh, J. (2014). Aktienrückkäufe gut oder schlecht für Investoren [Share buybacks good or bad for investors]? Schoellerbank Analysebrief Ausgabe Nr. 255, Juli 2014.

Freeman, R. E. (2010). Strategic management: A stakeholder approach. Cambridge University Press.

Frei, N. \& Schlienkamp, C. (1999). Aktie im Fokus [Share in focus].

Guserl, R., \& Pernsteiner, H. (2015). Kapitalstruktur und Dividendenpolitik [Capital structure and dividend policy]. In Finanzmanagement, (pp. 407-424). Gabler Verlag. http://spindices.com

Johannsen-Roth, T. (2001). Der Erwerb eigner Aktien: Inaugural-Dissertation zur Erlangung der Doktorwürde einer Hohen Rechtswissenschaftlichen Fakultät der Universität zu Köln. Universität Köln [The acquisition of own shares: Inaugural Dissertation to obtain the doctorate of a High Law Faculty of the University of Cologne. University of Cologne].

Lembke, M. (2009). Accounting policies In the individual financial statements in accordance with HGB and IAS/IFRS in comparison. BoD-Books on Demand.

Lembke, M. (2009). Bilanzpolitik Im Einzelabschluss nach HGB und IAS/IFRS Im Vergleich. BoD-Books on Demand.

Macharzina, K., \& Wolf, J. (2008). Unternehmensführung: das internationale Managementwissen; Konzepte, Methoden, Praxis [Corporate governance: international management knowledge; Concepts, methods, practice]. Springer-Verlag.

Miller, M. H., \& Modigliani, F. (1961). Dividend policy, growth, and the valuation of shares. The Journal of Business, 34 (4), $411-433$.

Modigliani, F., \& Miller, M. H. (1958). The cost of capital, corporation finance and the theory of investment. The American economic review, 48(3), 261-297. 


\section{ENTREPRENEURSHIP AND SUSTA International Journal \\ The International Journal}

ISSN 2345-0282 (online) http://jssidoi.org/jesi/

2018 Volume 6 Number 2 (December)

http://doi.org/10.9770/jesi.2018.6.2(12)

Pernsteiner, H., \& Andeßner, R. (2014). Finanzmanagement kompakt:(Ausgabe Österreich). [Financial Management compact: (Edition Austria)] Linde Verlag GmbH.

Perridon, L., Steiner, M., \& Rathgeber, A. W. (2014). Finanzwirtschaft der Unternehmung. [Financial economy of the enterprise].Vahlen.

Porter, M. E. (2013). Wettbewerbsstrategie: Methoden zur Analyse von Branchen und Konkurrenten [Competitive strategy: techniques for analyzing industries and competitors]. Campus Verlag.

Portisch, W. (Ed.). (2008). Finanzierung im Unternehmenslebenszyklus [Financing in the business life cycle]. Walter de Gruyter.

Prätsch, J., Schikorra, U., \& Ludwig, E. (2012). Finanzmanagement: Lehr-und Praxisbuch für Investition, Finanzierung und Finanzcontrolling [Financial management: teaching and practice book for investment, finance and financial controlling]. Springer-Verlag.

Schewe, G. (2005). Unternehmensverfassung: corporate governance im Spannungsfeld von Leitung, Kontrolle und Interessenvertretung. [Corporate constitution: corporate governance in the field of tension of management, control and representation of interests] Springer.

Schierenbeck, Henner. Grundzüge der Betriebswirtschaftslehre [Basics of Business Administration]. Walter de Gruyter.

Schmal, S. (2016). Datenbasis und Untersuchungsmethoden. In Konsolidierungswellen und Prognoseverhalten von Finanzanalysten [Database and research methods. In consolidation waves and forecasting behavior of financial analysts] (pp. 169-206). Springer Fachmedien Wiesbaden.

Schmidlin, N. (2013). Unternehmensbewertung \& Kennzahlenanalyse: Praxisnahe Einführung mit zahlreichen Fallbeispielen börsennotierter Unternehmen [Business Valuation \& Key Data Analysis: Practical introduction with numerous case studies of listed companies]. Vahlen.

Schremper, R. (2002). Aktienrückkauf und Kapitalmarkt: eine theoretische und empirische Analyse deutscher Aktienrückkauf programme [Share buyback and capital market: a theoretical and empirical analysis of German share buyback programs]. Lang.

Sendel-Müller, M. (2009). Aktienrückkäufe und Effizienz der Aufsichtsratsarbeit [Share buybacks and efficiency of the work of the Supervisory Board. Düsseldorf] (Hans Böckler Stiftung).

Staroßom, H. (2012). Corporate Finance Teil 2: Finanzierung in den Lebensphasen einer Unternehmung Corporate Finance Part 2: [Financing during the life stages of a company] (Vol. 2). Springer-Verlag.

Vienna Stock Exchange: https://www.wienerborse.at/uploads/u/cms/files/legal/stock-exchange-act.pdf

Wagenhofer, A. (2008). Bilanzierung, 2008: Bilanzierung \& Bilanzanalyse - Eine aktuelle und umfassende Einführung in die Bilanz, 9. Auflage, Wien. [Accounting, 2008: Accounting \& Balance Sheet Analysis - A recent and comprehensive introduction to the balance sheet, 9th edition, Vienna].

Walchshofer, M. (2013). Debt Relations mit Institutionellen Investoren. In Praxishandbuch Debt Relations Debt Relations with Institutional Investors. In Practice Handbook Debt Relations (pp. 219-229). Springer Fachmedien Wiesbaden.

Walchshofer, M. (2013). Debt Relations with Institutional Investors. In Practice Handbook Debt Relations (pp. 219-229). Springer Fachmedien Wiesbaden.

Wentges, P. (2013). Corporate governance and stakeholder approach: implications for corporate finance (Vol. 302). Springer-Verlag.

Wentges, P. (2013). Corporate governance und Stakeholder-Ansatz: Implikationen für die betriebliche Finanzwirtschaft (Vol. 302). Springer-Verlag. 
The International Journal

ENTREPRENEURSHIP AND SUSTAINABILITY ISSUES

ISSN 2345-0282 (online) http://jssidoi.org/jesi/

2018 Volume 6 Number 2 (December)

http://doi.org/10.9770/jesi.2018.6.2(12)

\section{Daniel SCHWARZ}

ORCID ID: https://orcid.org/0000-0002-0099-4389

Register for an ORCID ID:

https://orcid.org/register

Copyright (C) 2018 by author(s) and VsI Entrepreneurship and Sustainability Center

This work is licensed under the Creative Commons Attribution International License (CC BY).

http://creativecommons.org/licenses/by/4.0/

(c) (i) Open Access 